\title{
HUBUNGAN POLA ASUH ORANG TUA DENGAN PERILAKU ANAK KELAS 3 SDN MALANGJIWAN KECAMATAN COLOMADU KABUPATEN KARANGANYAR
}

\author{
Oleh : \\ Endang Dwi Ningsih ${ }^{1}$, Agnes Rivanti ${ }^{2}$
}

\begin{abstract}
Introduction: Parenting parents against children is the interaction between children and parents during the conduct of activities nurture, educate, guide and discipline and protecting the child to reach maturity in accordance with the norms prevailing in society. Family influence in the formation and development of the child's personality is very large because the family is the first social group where children can interact, where children learn and express themselves as social beings.

Purpose of the study: was to determine the relationship between parenting parents with a child's behavior.

Subjects: were 31 children grade 3 SDN Malangjiwan Colomadu. The sampling technique used is saturated sampling where all subjects are used as the sample. The datas are collected by questionnaire method for a variable pattern of parenting and child behavior, the data were analyzed with Chi Square test. The results were obtained for 0,032 there for $p<0.05$.
\end{abstract}

Conclusion: of this research is there is a relationship between parenting parents with a child's behavior grade 3 SDN malangjiwan Colomadu.

Keywords: Parenting, child behavior

\section{PENDAHULUAN}

Pola pengasuhan anak adalah salah satu faktor yang sangat mempengaruhi bagaimana masa depan anak nantinya. Sebagai orang tua sering kali tidak menyadari bahwa tahun-tahun pertama kehidupan anak merupakan waktu yang sangat menentukan dalam hal tumbuh kembang fisik, mental, dan psikososialnya. Dan semua itu berjalan begitu cepatnya sehingga keberhasilan tahun-tahun pertama dalam hal pengasuhan anak sangat besar pengaruhnya terhadap hari depan anak. (Ananda, 2011)

Bentuk pola asuh orang tua terhadap anak merupakan interaksi antara anak dan orang tua selama mengadakan kegiatan pengasuhan, mendidik, membimbing, dan mendisiplin serta melindungi anak untuk mencapai kedewasaan sesuai dengan norma-norma yang berlaku dimasyarakat. Pola asuh sangat mempengaruhi peran dan fungsi keluarga. Pengaruh keluarga dalam pembentukan dan perkembangan kepribadian anak sangat besar karena keluarga merupakan kelompok sosial yang pertama dimana anak dapat berinteraksi, tempat anak belajar, dan menyatakan dirinya sebagai makhluk sosial. Keluarga juga dapat memberikan dasar pembentukan tingkah laku, watak, moral, dan pendidikan kepada anak. Suatu keluarga ditandai dengan adanya orang tua, baik ayah maupun ibu. orang tua sebagai koordinator keluarga harus berperilaku proaktif. Jika anak menentang otoritas, segera ditertibkan karena dalam keluarga terdapat aturan-aturan. Diantara anggota keluarga saling 
mendengarkan jika bicara bersama, melalui teladan dari dorongan orang tua. (Kartono, 2010)

Pola pertumbuhan dan perkembangan manusia sudah ditentukan sejak masih dalam kandungan. Setiap sel tumbuh dan berkembang sesuai pola perkembangan masing-masing, yang semua mengarah pada satu tujuan menjadi makhluk manusia dengan organ-organ yang tersusun secara serasi. Perilaku manusia tidak terlepas dari proses pematangan organ-organ tubuh. Sebagai ilustrasi bahwa seorang bayi belum dapat duduk atau berjalan apabila organ-organ tubuhnya belum cukup kuat untuk menopang tubuh. Oleh karena itu, perlu pematangan tulang belakang terutama, tulang leher, punggung, pinggang, dan tulang kaki. Selain itu juga, seorang bayi tidak akan berjalan dulu sebelum dapat duduk, atau duduk dulu sebelum tengkurap, dan sebagainya. Perilaku individu tidak timbul dengan sendirinya, tetapi akibat adanya rangsangan (stimulus), baik dari dalam dirinya (internal) maupun dari luar diri individu (eksternal). Pada hakikatnya perilaku individu mencakup perilaku yang tampak (overt behavior) dan atau perilaku yang tidak nampak (innert behavior atau covert behavior). (Sunaryo, 2004)

Berdasarkan survey dan pengamatan awal pada siswa-siswi SDN 03 Malangjiwan Kecamatan Colomadu Kabupaten Karanganyar, yang rumahnya berdekatan dengan peneliti, dapat diperoleh data, beberapa anak usia SD menunjukkan perilaku yang baik, sopan dan ceria, tetapi sebagian yang lain menunjukkan perilaku yang minder, melihat orang baru takut dan diam bila ditanya. Dan bila melihat pola pengasuhan orang tua anak-anak tersebut, nampak bahwa masing-masing memiliki cara yang berbeda-beda.
Berdasarkan uraian latar belakang di atas, maka peneliti tertarik untuk melakukan penelitian tentang hubungan pola asuh orang tua dengan perilaku anak kelas 3 di SDN 06 Malangjiwan Kecamatan Colomadu Kabupaten Karanganyar.

\section{TUJUAN PENELITIAN}

Tujuan Umum

Untuk mengetahui hubungan pola asuh orang tua dengan perilaku anak kelas 3 di SDN 06 Malangjiwan Kecamatan Colomadu Kabupaten Karanganyar.

\section{Tujuan Khusus}

Adalah untuk mengetahui macammacam pola asuh orang tua dan perilaku pada anak kelas 3 di SDN 06 Malangjiwan Kecamatan Colomadu Kabupaten Karanganyar.

\section{DESAIN PENELITIAN}

Desain penelitian merupakan bentuk rancangan yang digunakan dalam melakukan prosedur penelitian. Desain penelitian yang umumnya digunakan di bidang keperawatan adalah rancangan penelitian deskriptif (korelasi, cross sectional), rancangan observasional (case control, kohort), dan rancangan intervensi atau eksperimen (pre post experimental, true experimental, dan quasy experimental). (Hidayat, 2008) Desain penelitian atau disebut juga rancangan penelitian ditetapkan dengan tujuan agar penelitian dapat dilakukan dengan efektif dan efisien. ( Suyanto, 2011)

Penelitian yang berjudul hubungan pola asuh orang tua dengan perilaku anak kelas 3 di SDN 06 Malangjiwan Kecamatan Colomadu Kabupaten Karanganyar, adalah merupakan penelitian analitik dengan desain korelasi untuk mengetahui hubungan pola asuh orang tua sebagai variabel bebas (independent variable) dengan perilaku anak sebagai variabel terikat (dependent variable). Sedangkan desain cross sectional 
merupakan rancangan penelitian yang pengukurannya atau pengamatannya dilakukan secara simultan pada suatu saat. ( Hidayat, 2008)

\section{POPULASI, SAMPEL, DAN TEHNIK SAMPLING}

Menurut Sugiono (2004), sebagaimana yang dikutip oleh Hidayat (2009), Populasi adalah wilayah generalisasi yang terdiri atas obyek atau subyek yang mempunyai kuantitas dan karakteristik tertentu yang ditetapkan oleh peneliti untuk dipelajari dan kemudian ditarik kesimpulannya. Jadi, populasi tidak hanya terbatas pada orang, tetapi juga benda alam yang lain.

Populasi juga bukan sekedar jumlah yang ada pada objek atau subjek yang dipelajari, tetapi meliputi seluruh karakteristik atau sifat yang dimiliki oleh objek atau subjek tersebut. (Hidayat, 2009) Populasi pada penelitian ini adalah seluruh siswa kelas 3 di SDN 06 Malangjiwan Kecamatan Colomadu Kabupaten Karanganyar yang berjumlah 33 anak.

Sampel merupakan bagian populasi yang akan diteliti atau sebagian jumlah dari karakteristik yang dimiliki oleh populasi. Dalam penelitian keperawatan, kriteria sampel meliputi kriteria inklusi dan kriteria eksklusi, dimana kriteria tersebut menentukan dapat dan tidaknya sampel tersebut digunakan. (Hidayat, 2009)

Sampel pada penelitian ini adalah seluruh populasi yaitu siswa kelas 3 di SDN 06 Malangjiwan Kecamatan Colomadu Kabupaten Karanganyar sebanyak 33 anak.

Tehnik sampling merupakan suatu proses seleksi sampel yang digunakan dalam penelitian dari populasi yang ada, sehingga jumlah sampel akan mewakili seluruh populasi yang ada. (Hidayat, 2009) Dalam penelitian ini peneliti menggunakan teknik sampling jenuh. Teknik sampling jenuh adalah pengambilan sampel dengan mengambil semua anggota populasi menjadi sampel. (Hidayat, 2009) Pada penelitian ini sampel yang digunakan adalah seluruh siswa kelas 3 di SDN 06 Malangjiwan Kecamatan Colomadu Kabupaten Karanganyar sebanyak 33 anak.

\section{HASIL PENELITIAN}

Pada penelitian ini peneliti akan menguraikan hasil penelitian dengan judul Hubungan Pola Asuh Orang Tua dengan Perilaku Anak Kelas 3 di SDN Malangjiwan Kecamatan Colomadu. Penelitian ini dilakukan pada bulan Februari 2015 dengan jumlah responden sebanyak 31 anak. Penelitian dilakukan dengan menyebarkan kuesioner tentang pola asuh orang tua dan perilaku anak pada anak kelas 3 SDN Malangjiwan Colomadu. Peneliti datang ke kelas 3 SDN Malangjiwan sebanyak 2 (dua) kali untuk mendampingi waktu responden mengisi kuesioner

Selama melakukan penelitian peneliti tidak menemukan hambatan dikarenakan peneliti memantau langsung sehingga responden yang tidak memahami pernyataan pada kuesioner dapat langsung bertanya. Secara umum proses pengumpulan data dapat berjalan secara lancar.

$\mathrm{Di}$ bawah ini akan dipaparkan karakteristik responden berdasarkan jenis kelamin, agama dan postur tubuh serta pekerjaan orang tua dapat dipaparkan sebagai berikut :

1. Karakteristik Responden a. Berdasarkan jenis kelamin 
Tabel 1. Distribusi Frekuensi

Responden Berdasarkan Jenis Kelamin

\begin{tabular}{lcc}
\hline $\begin{array}{c}\text { Jenis } \\
\text { Kelamin }\end{array}$ & $\mathbf{f}$ & $\%$ \\
\hline Laki-Laki & 20 & 60 \\
\hline Perempuan & 11 & 40 \\
\hline Jumlah & 31 & 100 \\
\hline
\end{tabular}

Dari tabel di atas diperoleh informasi bahwa sebagian besar responden berjenis kelamin laki laki berjumlah 20 anak $(60 \%)$ dan jumlah responden paling sedikit berjenis kelamin perempuan berjumlah 11 anak ( $40 \%$ ).

b. Berdasarkan agama

Tabel 2. Distribusi Frekuensi Responden Berdasarkan Agama

\begin{tabular}{lcc}
\hline Agama & f & $\%$ \\
\hline Islam & 30 & 96 \\
\hline $\begin{array}{l}\text { Kristen } \\
\text { Katolik }\end{array}$ & 1 & 4 \\
\hline Jumlah & 31 & 100 \\
\hline
\end{tabular}

Dari tabel di atas diperoleh informasi bahwa sebagian besar responden beragama Islam berjumlah 30 anak (96\%) dan jumlah responden paling sedikit adalah beragama Kristen Katolik berjumlah 1 anak ( $4 \%$ ).

c. Berdasarkan postur tubuh anak

Tabel 3. Distribusi Frekuensi Responden Berdasarkan Postur Tubuh

\begin{tabular}{lcc}
\hline Postur tubuh & f & $\%$ \\
\hline BB Gemuk & 7 & 33 \\
\hline BB Normal & 24 & 77 \\
\hline Jumlah & 31 & 100 \\
\hline
\end{tabular}

Dari tabel di atas diperoleh informasi bahwa sebagian besar responden berpostur tubuh normal berjumlah 24 anak $(77 \%)$ dan jumlah responden paling sedikit adalah berpostur gemuk berjumlah 7 anak (33\%).

d. Berdasarkan pekerjaan orang tua

Tabel 4. Distribusi Frekuensi Responden Berdasarkan Pekerjaan Orang Tua

\begin{tabular}{lcc}
\hline $\begin{array}{l}\text { Pekerjaan } \\
\text { orang tua }\end{array}$ & $\mathbf{f}$ & $\%$ \\
\hline Pegawai Negeri & 14 & 45 \\
\hline Pegawai Swasta & 10 & 32 \\
\hline Wiraswasta & 7 & 23 \\
\hline Jumlah & 31 & 100 \\
\hline
\end{tabular}

Dari tabel di atas diperoleh informasi bahwa pekerjaan orang tua responden adalah pegawai negeri berjumlah 14 anak (45\%), pegawai swasta berjumlah 10 anak (32\%) dan wiraswasta berjumlah 7 anak (23\%).

2. Variabel pola asuh orang tua

Tabel 5. Distribusi Frekuensi Variabel Pola Asuh Orang Tua

\begin{tabular}{lcc}
\hline $\begin{array}{l}\text { Pola Asuh } \\
\text { Orang Tua }\end{array}$ & $\mathbf{f}$ & $\%$ \\
\hline Otoriter & 6 & 19 \\
\hline Permisif & 3 & 10 \\
\hline Demokrasi & 22 & 71 \\
\hline Jumlah & 31 & 100 \\
\hline
\end{tabular}

Dari tabel di atas ditemukan frekuensi paling banyak pada pola asuh demokrasi yaitu 22 responden (71 \%), sedangkan frekuensi paling sedikit pada pola asuh permisif yaitu 3 responden (6\%). 
3. Variabel perilaku anak

Tabel 6. Distribusi Frekuensi Variabel Perilaku Anak

\begin{tabular}{ccc}
\hline Perilaku Anak & $\mathbf{f}$ & $\%$ \\
\hline Aktif & 21 & 68 \\
\hline Pasif & 10 & 32 \\
\hline Jumlah & 31 & 100 \\
\hline
\end{tabular}

Dari tabel di atas ditemukan frekuensi paling banyak pada perilaku aktif yaitu 21 responden (68 \%), sedangkan frekuensi paling sedikit pada perilaku pasif yaitu 10 responden (32\%).

4. Hubungan pola asuh orang tua dengan perilaku anak

Tabel 7. Hubungan Variabel Pola Asuh Orang Tua dengan Perilaku Anak

\begin{tabular}{lccc}
\hline Pola Asuh & \multicolumn{3}{c}{ Perilaku anak } \\
\cline { 2 - 4 } Orang Tua & Aktif & Pasif & Jumlah \\
\hline Otoriter & 2 & 4 & 6 \\
\hline Permisif & 1 & 2 & 3 \\
\hline Demokrasi & 18 & 4 & 22 \\
\hline Jumlah & 21 & 10 & 31 \\
\hline
\end{tabular}

Berdasarkan tabel di atas dapat dilihat bahwa :

a. Terdapat 6 anak dengan pola asuh otoriter, 2 anak menunjukkan perilaku aktif dan 4 anak dengan perilaku pasif

b. Terdapat 3 anak dengan pola asuh permisif, 1 anak menunjukkan perilaku aktif dan 2 anak dengan perilaku pasif

c. Terdapat 22 anak dengan pola asuh demokrasi, 18 anak menunjukkan perilaku aktif dan 4 anak dengan perilaku pasif

Berdasarkan hasil uji dengan menggunakan Chi Square menggunakan program SPSS for windows seri 18 dengan $\alpha=5 \%$ (0.05) diperoleh $p$ sebesar 0,032 sehingga $p<0.05$, yang berarti hipotesa diterima maka dapat ditarik kesimpulan bahwa ada hubungan antara pola asuh orang tua dengan perilaku anak kelas 3 SDN Malangjiwan Colomadu.

\section{PEMBAHASAN}

1. Variabel Pola Asuh Orang Tua Berdasarkan tabel 5 dapat dilihat bahwa frekuensi paling banyak pada pola asuh demokrasi. Pola pengasuhan anak adalah merupakan salah satu faktor yang sangat mempengaruhi bagaimana masa depan anaknya nanti. (Ananda, 2011) Bentuk pola asuh orang tua terhadap anak merupakan interaksi antara anak dan orang tua selama mengadakan kegiatan pengasuhan, mendidik, membimbing dan mendisiplin serta melindungi anak untuk mencapai kedewasaan sesuai dengan norma-norma yang berlaku di masyarakat. Pengaruh keluarga dalam pembentukan dan perkembangan kepribadian anak sangat besar karena keluarga merupakan kelompok sosial yang pertama dimana anak dapat berinteraksi, tempat anak belajar dan menyatakan dirinya sebagai makhluk sosial. Keluarga juga dapat memberikan dasar pembentukan tingkah laku, watak, moral dan pendidikan kepada anak. (Kartono, 2010)

Sebagaimana hasil yang
dipaparkan pada tabel 5
menunjukkan pengasuhan yang diterapkan orang tua untuk anak kelas 3 di SDN Malangjiwan pada pola asuh demokrasi yakni orang tua sangat memperhatikan kebutuhan anak dan mencukupi dengan pertimbangan faktor kepentingan dan kebutuhan. ( Septiari, 2012) Pada pola asuh demokrasi orang tua memberikan aturan - aturan yang jelas, dan menjelaskan 
akibat yang terjadi apabila peraturan dilanggar. Dengan aturan yang selalu diulang ulang diharapkan anak dapat memahami, memberi kesempatan pada anak untuk berpendapat, anak diberi pujian atau hadiah apabila telah berbuat sesuatu sesuai dengan harapan orang tua, sehingga anak memiliki kemampuan sosialisasi yang baik, memiliki rasa percaya diri dan bertanggungjawab.

Pada tabel juga dapat dipaparkan, bahwa pola asuh otoritatif dialami oleh 6 anak dan pola asuh permisif dialami oleh 3 anak, dalam hal ini orang tua harus mulai menyadari bahwa dengan pengasuhan yang demikian akan berdampak tidak positif bagi anak, karena pemaksaan kehendak orang tua, anak tidak boleh mengeluarkan pendapat atau anak boleh berbuat apa saja bahkan orang tua cenderung memberi kebebasan untuk berbuat apa saja sebagaimana yang disampaikan oleh Septiari (2012) akan memberi pengaruh pada perkembangan mental anak terutama pada prestasi sekolah, anak dapat menjadi anak pemalas dan tidak peduli/ tidak bertanggungjawab.

\section{Variabel Perilaku anak}

Berdasarkan tabel 6 menunjukkan bahwa perilaku anak lebih banyak menunjukkan pada perilaku aktif yaitu 21 anak (68\%). Perilaku adalah suatu kegiatan atau aktivitas organisme yang bersangkutan, yang dapat diamati secara langsung maupun tidak langsung. (Sunaryo, 2004) Adapun proses pembentukan perilaku didasari adanya kebutuhan, dimana sifat dan jenis kebutuhan satu sama lain tidak dapat dipisahkan karena merupakan satu kesatuan atau rangkaian walaupun pada hakekatnya kebutuhan fisiologis merupakan faktor yang dominan untuk kelangsungan hidup manusia. ( Sunaryo, 2004) Dari tabel di atas menunjukkan bahwa perilaku anak yang lebih banyak adalah perilaku aktif yang merupakan respons ekternal dimana perilaku anak sifatnya terbuka, perilaku tersebut berupa tindakan- tindakan nyata yang dapat diamati secara langsung, contohnya mengerjakan ulangan, membaca buku pelajaran, atau bermain- main dengan teman sebayanya sebagaimana yang dikutip oleh Sunaryo (2004).

Adapun faktor yang mempengaruhi perilaku terdiri dari faktor genetik dan dari luar sebagaimana yang dikemukakan oleh Sunaryo (2004) antara lain : ras, jenis kelamin, sifat fisik, kepribadian, pembawaan, intelegensia, lingkungan, pendidikan, agama, sosial ekonomi dan kebudayaan. Hal ini sesuai dengan yang dipaparkan pada karakteristik responden menunjukkan yaitu :

a. Responden yang paling banyak adalah laki - laki, lakilaki berperilaku atas dasar pertimbangan rasional atau akal dan lebih banyak gerak atau aktif dibanding perempuan, maka hal ini sesuai apabila respon yang banyak muncul adalah respon aktif.

b. Responden paling banyak beragama Islam, meskipun tidak diteliti pengaruh agama terhadap banyaknya respons ekternal, tetapi dalam pembentukan perilaku agama dapat memberi pengaruh juga.

c. Responden paling banyak berpostur tubuh normal artinya berat badan seimbang, maka bila perilaku anak lebih banyak pada perilaku aktif karena 
anak- anak memiliki sifat fisik yang lebih mudah untuk melakukan kegiatan dibandingkan sifat fisik anak yang gemuk.

d. Responden paling banyak memiliki orang tua yang bekerja sebagai pegawai negeri, hal ini tentunya faktor lingkungan, pendidikan, sosial ekonomi dan kebudayaan yang berkembang pada keluarga memberi pengaruh pada pembentukan perilaku aktif anak sangat signifikan.

3. Hubungan Pola Asuh Orang Tua dengan Perilaku Anak

Berdasarkan tabel 7 dapat diperoleh hasil 6 anak dengan pola asuh otoriter, 2 anak menunjukkan perilaku aktif dan 4 anak dengan perilaku pasif, 3 anak dengan pola asuh permisif, 1 anak menunjukkan perilaku aktif dan 2 anak dengan perilaku pasif, dan 22 anak dengan pola asuh demokrasi, 18 anak menunjukkan perilaku aktif dan 4 anak dengan perilaku pasif. Jadi pada pola asuh orang tua yang demokrasi anak lebih menunjukkan perilaku yang aktif.

Dari hasil uji Chi Square dengan menggunakan program dan SPSS versi 18 dengan a $5 \%$ $(0,05)$ diperoleh $p$ sebesar 0,032 sehingga $p<0,05$ berarti hipotesa diterima dengan kesimpulan ada hubungan antara pola asuh orang tua dengan perilaku anak kelas 3 SDN Malangjiwan Colomadu.

Hal di atas menunjukkan bahwa latar belakang pengasuhan anak tentu sangat berpengaruh terhadap perkembangan anak selanjutnya, sebab hal - hal yang didapat anak dari pola pengasuhan orang tuanya akan menjadi bekal sikap dan perilaku pada kehidupan anak kelak. Keluarga memiliki peranan yang sangat penting dalam upaya mengembangkan pribadi anak. Perawatan orang tua yang penuh kasih sayang dan pendidikan tentang nilai - nilai kehidupan baik agama maupun sosial budaya yang diberikan merupakan faktor yang kondusif untuk mempersiapkan anak menjadi pribadi dan anggota masyarakat yang sehat, sebagaimana yang dikutip oleh Ananda ( 2011), bahwa pola pengasuhan anak adalah salah satu faktor yang sangat mempengaruhi bagaimana masa depan anak nantinya, pola asuh orang tua adalah bagaimana orang tua memperlakukan anak, mendidik, membimbing dan mendisiplin anak dalam mencapai proses kedewasaan pada upaya pembentukan norma - norma yang diharapkan masyarakat. ( Septiari, 2012) Jadi pola asuh demokrasi sangat memberi dampak positif pada perkembangan anak untuk membentuk anak memiliki respons eksternal yang lebih mendukung perkembangannya, karena orang tua sangat memperhatikan kebutuhan anak dan memberi pengasuhan sesuai kepentingan dan kebutuhan anak. (Septiari, 2012).

Sebagaimana yang dipaparkan pada tabel 5 menunjukkan anak yang mengalami pengasuhan otoritatif dan permisif ada yang menunjukkan perilaku aktif, dalam hal ini belum dikaji secara mendalam apakah pola pengasuhan tersebut baik untuk masa depan anak dan juga respon eksternal yang dilakukan anak apakah memiliki manfaaat untuk pembentukan kepribadian anak, karena kepribadian anak sangat dipengaruhi oleh pola asuh yang diberikan keluarga sejak dini, maka orang tua harus sangat hati-hati. (Ananda, 2011) 
Diharapkan dengan gaya pengasuhan anak yang tepat, anak dapat berkembang menjadi pribadi yang baik dan bermanfaat untuk masa depannya.

Hasil penelitian ini juga sesuai dengan penelitian terdahulu yang diteliti oleh Raharizky (2012) dengan judul Pengaruh Pola Asuh Orang Tua terhadap Perilaku Disiplin Anak Usia Dini di Rumah pada Kelompok bermain An-Nur, Ulil Albab dan ALGhufron Malang dengan hasil bahwa ada pengaruh pola asuh orang tua terhadap perilaku disiplin anak usia dini di rumah dengan nilai 0,852 pada pola asuh demokrasi.

\section{KESIMPULAN}

Dari hasil penelitian yang berjudul hubungan pola asuh orang tua dengan perilaku anak dapat diperoleh kesimpulan sebagai berikut :

1. Terdapat 6 anak dengan pola asuh otoriter, 2 anak menunjukkan perilaku aktif dan 4 anak dengan perilaku pasif, 3 anak dengan pola asuh permisif, 1 anak menunjukkan perilaku aktif dan 2 anak dengan perilaku pasif, dan 22 anak dengan pola asuh demokrasi, 18 anak menunjukkan perilaku aktif dan 4 anak dengan perilaku pasif. Jadi pada pola asuh orang tua yang demokrasi anak lebih menunjukkan perilaku yang aktif.

2. Dari hasil uji Chi Square dengan menggunakan program dan SPSS versi 18 dengan a 5\% $(0,05)$ diperoleh $p$ sebesar 0,032 sehingga $p<0,05$ berarti hipotesa diterima dengan kesimpulan ada hubungan antara pola asuh orang tua dengan perilaku anak kelas 3 SDN Malangjiwan Colomadu.

\section{SARAN}

1. Bagi orang tua (masyarakat) diharapkan hasil penelitian ini dapat memberi pemahaman kepada orang tua agar memberikan dan menerapkan pengasuhan secara demokrasi pada anak agar anak memiliki/ menunjukkan perilaku aktif atau banyak memberikan respon eksternal yang berkembang menuju pendewasaan kepribadian yang bermanfaat untuk masa depannya dan perlunya bagi orangtua yang menerapkan pengasuhan otoriter dan permisif untuk memahami hakekat pengasuhan dan tanggung jawab sebagai orang tua agar masa depan anak - anaknya bermanfaat untuk masyarakat dan bangsa.

2. Bagi Peneliti Selanjutnya, diharapkan dapat digunakan sebagai dasar untuk penelitian selanjutnya yang berkaitan dengan pola asuh anak.

\section{KETERBATASAN}

Penelitian ini memiliki keterbatasan antara lain :

1. Penelitian yang dilakukan hanya mengambil populasi pada siswa kelas 3 SDN Malangjiwan Colomadu sehingga hasil penelitian tidak dapat digeneralisasi.

2. Instrumen penelitian yang digunakan kepada responden hanya melalui pengisian kuesioner dan tidak dilakukan wawancara langsung sehingga peneliti sulit mengendalikan responden. 
DAFTAR PUSTAKA

Ananda, Rizka. Membangun Karakter Positif Buah Hati. Yogyakarta: Razan Media Press, 2011.

Ariani, Ayu Putri. Aplikasi Metodologi Penelitian Kebidanan dan Kesehatan Reproduksi. Yogyakarta: Nuha Nedika, 2014.

Hidayat, A. Aziz Alimul. Metode Penelitian Keperawatan dan Teknik Analisis Data. Jakarta: Salemba Medika, 2009.

.Riset Keperawatan dan Teknik Penulisan IImiah. Jakarta: Salemba Medika, 2008.

Nurul, Chomaria. 25 Perilaku Anak dan Solusinya. Jakarta: PT Elek Media Komputindo, 2013.

Septiari, Bety Bea. Mencetak Balita Cerdas dan Pola Asuh Orang Tua. Yogyakarta: Nuha Medika, 2012.

Sunaryo. Pisikologi untuk Keperawatan. Jakarta: EGC, 2004.

Widyarini, Nilam. Relasi Orang Tua dan Anak. Jakarta: PT Elex Media Komputindo, 2009.
Farid, Muhammad. Hubungan Penalaran Moral, Kecerdasan Emosi, Religiusitas, dan Pola Asuh Orang Tua Otoritatif dengan Perilaku Proposal Remaja. 2011. Diunduh tanggal 3 November 2014.

Raharizky, Yani Arwidhi. Pengaruh Pola Asuh Orang Tua Terhadap Perilaku Disiplin Anak Usia Dini di Rumah (Studi Pada Orang Tua Peserta Didik Kelompok Bermain Ulil Albab, Kelompok Bermain An-Nur, dan Kelompok Bermain Al-Ghufron Malang). 2012. Diunduh tanggal 3 November 2014.

Kartono, Hubungan Pola Asuh Orang Tua terhadap Perilaku Remaja di Keluhan Simalingkar B, Kecamatan Medan Tuntungan. Diunduh tanggal 1 November 2014.

1 Dosen AKPER Panti Kosala Surakarta

2 Mahasiswa AKPER Panti Kosala Surakarta 